\title{
SYSTEMATIC AND SIMPLE COST-BENEFIT INVESTIGATION OF SOME AdVANTAgES OF THE REgENERATIVE AgRICULTURE
}

\author{
Zsolt HETESI \\ National University of Public Service, Faculty of Water Sciences, H-1083 Budapest, Ludovika tér 2.
}

\begin{abstract}
Regenerative agriculture aims to stop soil degradation with some systematic steps of advantageous treatments i.e. no-till, using crop covers, etc. It is considered as one of the best candidates to capture anthropogenic CO2 from the atmosphere via natural carbon cycle of plants. However, its measure is not certain yet and it is a bone of contention now. But this method has some other useful consequences as well. We try to calculate their fiscal advantages.
\end{abstract}

Keywords: soil degradation, climate changes, cost-benefit, regenerative agriculture

\section{INTRODUCTION}

Hungary is situated in the temperate climatic zone, its climate and weather are significantly affected by the climate change. One of the most important economical fields, agriculture is largely subjected to the changes in the climate. Not only climate change itself influences adversely the agricultural production but the harmful effects caused by the industrial agriculture in the soil, therefore soil as a natural resource is in danger due to the climate change and intensive tillage as well. Agriculture has to adapt to these new challenges.

There are only few good practices existing, however one of them, so-called regenerative agriculture is a promising medicine for the above mentioned problems. There has been a robust debate recently on this method's ability to sequester carbondioxide from the atmosphere, but the other positive effects, which are indisputable, have not been investigated from the point of view of a simple cost-benefit analysis. In this paper some aspects of this question are investigated.

\section{DETAILED RISKS IN CROP PRODUCTION}

\section{Changes in weather due to the climate change}

In Hungary, thanks to the stability of the climate, there has been a crop production system which considered the order of seasons, the uniform distribution of precipitation as standard. Due to the past stability of these circumstances the present challenges and the relatively fast emergence of present weather anomalies, the crop production has not been able to adapt to the new circumstances. It was pointed out (Hetesi and Kiss, 2017) that the average temperature in Hungary had increased significantly (and exceeded the linear increase) and the number of extreme weather 
events had increased as well. E.g. there is significant increase in the daily precipitation in a concrete geographic coordinate or the number of days when average temperature exceeds $30 \mathrm{C}^{\circ}$ has increased significantly as well.

These phenomena mean that agriculture has to prepare for higher average temperatures in the future and to more extremity as well.

\section{Soil degradation}

The formation of soil is a slow process unlike the harmful effects of cultivation, the speed of the latter processes can be larger with one or two orders of magnitude in many cases. The FAO Report (2015) on the soils declares the soil degradation as one of the most urgent challenges we have been facing with. The crop cultivation machinery's contribution to soil degradation is significant. There is a historical example of this effect, the so called Dust Bowl in the 1930's on the Great Prairie, USA. Dust Bowl is the collective noun of those dust storms which was caused by the extremely drought and the incorrect cultivation practice used on the Prairie's fields (Young et al., 2015).

Recently the most common way of cultivation is ploughing, which contributes to the decrease of the humus content of soil. It was also observed if regenerative agriculture had been used and then terminated and the filed was ploughed again, the organic matter growth due to the regenerative cultivation diminished by setting back ploughing (Yang et al., 2008).

There is a further problem emerging due to ploughing, the so called plough pan phenomenon, which is formed by the weight of the plough itself and makes up a tight compact layer below the ploughed layer. This layer is not permeable either for most of the roots or water.

It means that the upper 25 to $35 \mathrm{~cm}$ layer of the soil has to receive and store the precipitation. Recently the precipitation can be extreme and the upper soil is not capable of storing the whole quantity of it (the cultivation also reduces the number of pores in the soil).

\section{A GOOD PRACTICE: REGENERATIVE AGRICULTURE}

There is a good practice, recently emerging, which may handle these problems adequately (degradation of soil, harmful effect of extreme weather events). The major elements of this practice are the lack of tillage or minimal tillage, a good crop rotation, and cover crops after the crop year of the main plant, e.g. corn, wheat or soybean. In natural systems the best soil can be found in the forest or on the prairie. On a bare soil the first step of the successive ecological level is the occurrence of pioneer plants (referred to as „weeds” in everyday speech). After them scrubs and later trees occur, meanwhile there is a strong interaction between roots and soil bacteria and later fungi to produce more humus and increase the organic matter content of the soil.

The remnant of the organic matter creates a mulch layer on the topsoil and at the bottom of this layer the early signs of soil formation occur. This layer is called moder in forests and mull on steppes. Recent studies pointed out that soil formation is very active when living roots and active bacteria and fungi presence can be observed in 
the soil. Crop covering ensures the presence of living roots in the major part of the year (Kallenbach et al, 2016; Sokol et al, 2018).

It seems to be obvious from these that a healthy usage of soil has to mimic the natural system's run. The aforementioned four elements of this practice need some more explanation.

1. Lack of tillage: it can be achieved by direct seed planters which are able to sow into a mulch layer. On smaller farms it is also a viable way to cultivate the topsoil without ploughing in the absence of direct planters.

2. After the main commercial crop (e.g. soybean or wheat) one has to sow a special combination of crop cover plants. Special means that there are different soil types with different properties and therefore a unique mix of cover crops does not exist that uniformly acts in every situation. There are many different advantageous effects of cover crops which can be used in different cases, e.g. oat with its large root mass is suitable for sandy soils to block erosion, or nitrogen fixation with using bean family plants, using daikon radish to break through the plough pan etc.

3. Living roots in the soil: during the crop year it is realized but after harvesting the commercial crop bare soil remains. Crop covering ensures living roots in the soil in late autumn as well.

4. Soil coverage: crop cover plants freeze during winter and create an organic layer on the topsoil (this method is similar to the natural system's work). The sowing at spring happens into this layer.

With these elements several advantages of this practice can be observed, which are beneficial to handle extreme weather effects or adapt to the climate change and are also cost effective as well.

1. Porosity of the topsoil increases during the use of crop cover plants, the elimination of the plough pan is also beneficial, these two effects increase the water storage capacity of the topsoil. Therefore, the exposure to extreme precipitation decreases.

2. Crop cover plants are good devices in weed control. Due to their large mass, dense stands and shadow, they are effective to control the growth of weeds.

3. Artificial nutrition with fertilizer is needed especially in the transitional period. The increase in the soil life needs more nutrition. After the dispersion of the soil bacteria and fungi the nutrition opens up.

\section{Systematic and cost advantages of regenerative agriculture}

If we compare the conventional and regenerative agriculture, we can find some sound differences (Table 1).

If we want to determine the financial benefits of this technology and calculate costs wherever it is possible, we can construct another table (Table 2). The results are partly based on personal experiences in a small farmland, with a tractor of $80 \mathrm{HP}$ used, cost data are from the NAIK (National Agricultural Reseach and Innovation centre Hungary) ${ }^{1}$

\footnotetext{
${ }^{1}$ https://agrarium7.hu/data/kepek/1000/eredeti/1435.jpg
} 
Table 1

\section{Systematic differences between agricultural systems}

\begin{tabular}{|l|l|l|}
\hline & \multicolumn{1}{|c|}{ Conventional } & \multicolumn{1}{c|}{ Regenerative } \\
\hline Water storage capacity & Porosity till 30 to $40 \mathrm{~cm}$ depth & Porosity till $40+\mathrm{cm}$ depth \\
\hline Nr of tillages per year & 5 or more & $\begin{array}{l}\text { None (no till); } \\
1-2 \text { (minimal till) }\end{array}$ \\
\hline Demand for chemicals & 1 (= conventional as base) & $0.2-0.5$ \\
\hline Yield & 1 (=conventional as base) & $0.8-1.1$ \\
\hline
\end{tabular}

Table 2

\section{Costs of steps in different agricultural systems}

\begin{tabular}{|c|c|c|c|c|c|c|}
\hline & \multicolumn{2}{|c|}{ Conventional } & \multicolumn{2}{|c|}{ No till } & \multicolumn{2}{|c|}{ Minimum till ${ }^{2}$} \\
\hline \multirow{3}{*}{$\begin{array}{l}\text { Costs of } \\
\text { cultivation }\end{array}$} & Ploughing & $15127 \mathrm{Ft}$ & \multirow{3}{*}{$\begin{array}{l}\text { Direct } \\
\text { sowing }\end{array}$} & \multirow{3}{*}{$6960 \mathrm{Ft}^{4}$} & Combinator & 0167 \\
\hline & $\begin{array}{l}\text { Seedbed } \\
\text { construction }\end{array}$ & $6059 \mathrm{Ft}$ & & & \multirow{2}{*}{$\begin{array}{l}\text { Seedbed } \\
\text { construction }\end{array}$} & \multirow{2}{*}{$6059 \mathrm{Ft}$} \\
\hline & $\begin{array}{l}\text { Stubble } \\
\text { elimination }\end{array}$ & $10167 \mathrm{Ft}$ & & & & \\
\hline $\begin{array}{l}\text { Crop cover } \\
\text { seed }\end{array}$ & & $0 \mathrm{Ft}$ & & $\begin{array}{c}25000- \\
45000 \mathrm{Ft}\end{array}$ & & $\begin{array}{r}25000- \\
45000 \mathrm{Ft}\end{array}$ \\
\hline \multirow{2}{*}{\begin{tabular}{|l|}
$\begin{array}{l}\text { Fertilizer } \\
\text { usage }\end{array}$ \\
\end{tabular}} & NPK & 1 & NPK & 0.25 & NPK & 0.25 \\
\hline & N27 & 1 & $\mathrm{~N} 27$ & 0.50 & $\mathrm{~N} 27$ & 0.50 \\
\hline \multirow{2}{*}{$\begin{array}{l}\text { Pesticide } \\
\text { usage }\end{array}$} & $\begin{array}{l}\text { Weed } \\
\text { control }\end{array}$ & 1 & \begin{tabular}{|l|} 
Weed \\
control
\end{tabular} & 0.25 & $\begin{array}{l}\text { Weed } \\
\text { control } \\
\end{array}$ & 0.25 \\
\hline & $\begin{array}{l}\text { Other } \\
\text { herbicides }\end{array}$ & 1 & $\begin{array}{l}\text { Other } \\
\text { herbicides }\end{array}$ & 1 & $\begin{array}{l}\text { Other } \\
\text { herbicides }\end{array}$ & 1 \\
\hline Yield & \multicolumn{2}{|c|}{1} & \multicolumn{2}{|c|}{0.9} & \\
\hline
\end{tabular}

\section{CONCLUSION}

Regenerative agriculture can improve the soil's water storage capacity, using crop covers and no till together can help to prevent the formation of plough pan effect. Because of this, the soil is a better source of water even if there are extreme precipitation events.

Leaving behind ploughing, one can save fuel and let soil conserve its structure which is the base of further soil formation. True or not that this type of practice is able to increase the organic matter content of soil, it indisputably contains other attractive and cost-beneficial advantages.

\footnotetext{
${ }^{2}$ These are partly personal observations of the author using this method.

${ }^{3}$ Direct sowing is considered here as cultivation process.

${ }^{4}$ Estimated by corn planting. Corn seed planters are similar to direct seed planters.
} 


\section{ACKNOWLEDGEMENTS}

The publication of this paper is supported by the EFOP-3.6.2-16-2017-00018 "Produce together with the nature - agroforestry as a new outbreaking possibility" project.

\section{REFERENCES}

Young, R., Orsini, S., FitzPatrick, I. (2015): Soil Degradation: a major threat to humanity. Bristol, UK: Sustainable Food Trust [online] <URL: http://www.fao.org/fsnforum/sites/default/files/discussions/contributions / Soil-degradation-Final-final_0.pdf $>$

Hetesi, Zs.; Kiss, T. (2017): Az éghajlatváltozás jövőben várható hatásairól In: Agrofórum - A növénytermesztők és növényvédők havilapja, 28. 2. 6-8. p.

Kallenbach, C.M., Frey, S.D., Grandy, A.S. (2016): Direct evidence for microbialderived soil organic matter formation and its ecophysiological controls. In: Nature Communications, 7. 1. doi:10.1038/ncomms13630

Sokol, N.W., Kuebbing, S.E., Karlsen-Ayala, E., Bradford, M.A. (2018). Evidence for the primacy of living root inputs, not root or shoot litter, in forming soil organic carbon. In: New Phytologist, 221. 1. 233-246. p. doi: 10.1111/nph.15361

Yang, X., Drury, C., Reynolds, W., Tan, C. (2008): Impacts of long-term and recently imposed tillage practices on the vertical distribution of soil organic carbon. In: Soil and Tillage Research, 100. 1-2. 120-124. p. doi:10.1016/j.still.2008.05.003

Corresponding author:

\section{Zsolt HETESI}

National University of Public Service,

Faculty of Water Sciences

H-1083 Budapest, Ludovika tér 2.

e-mail: hetesi.zsolt@uni-nke.hu 